\title{
Correction: Antigenic Properties of the Human Immunodeficiency Virus Envelope Glycoprotein Gp120 on Virions Bound to Target Cells
}

The PLOS Pathogens Staff

\section{Notice of Republication}

This article was republished on May 22, 2015, to correct Figures 5 and 6, which were both resized during the typesetting process. The publisher apologizes for the errors. Please download this article again to view the correct version.

\section{Reference}

1. Mengistu M, Ray K, Lewis GK, DeVico AL (2015) Antigenic Properties of the Human Immunodeficiency Virus Envelope Glycoprotein Gp120 on Virions Bound to Target Cells. PLoS Pathog 11(3): e1004772. doi: 10.1371/journal.ppat.1004772 PMID: 25807494

G openaccess

Citation: The PLOS Pathogens Staff (2015) Correction: Antigenic Properties of the Human Immunodeficiency Virus Envelope Glycoprotein Gp120 on Virions Bound to Target Cells. PLoS Pathog 11(6): e1004990. doi:10.1371/journal. ppat.1004990

Published: June 15, 2015

Copyright: @ 2015 The PLOS Pathogens Staff. This is an open access article distributed under the terms of the Creative Commons Attribution License, which permits unrestricted use, distribution, and reproduction in any medium, provided the original author and source are credited. 